\title{
The Role of Local Language in Intercultural Communication among Societies of Buru Island
}

\author{
S Z B Tahir ${ }^{*}$, R Bugis ${ }^{2}$, A Masniati ${ }^{3}$, A Y Tenriawali ${ }^{4}$, A Azwan ${ }^{5}$, D C \\ Oktavianti $^{6}$
}

${ }_{1,2,3,4,5, \& 6}{ }^{2}$ Universitas Iqra Buru, Maluku Jl. Prof. Dr. Abdurrahman Basalamah, M.Si, Namlea, Ambon, Maluku, Indonesia

*E-mail: saidnazulfiqar@gmail.com

\begin{abstract}
The cross-cultural communication often triggers the inter-community conflict. This research aimed at exploring the process and the function of the intercultural communication amongst societies in Buru Island. The subject of the study was the societies of Bassalale Village which has a diversity of the cultural background. This research employed a descriptive qualitative design. The researchers were applicable as the principal investigators (key instrument) which conduct the research process directly and actively in observing, interviewing, and gathering various materials relating to the intercultural communication among societies in Buru Island. To analyze the data, the researchers applied a model analysis by Miles and Huberman which consist of three elements; they are data reduction, display, and conclusion drawing. The results found that the role of Buru language in the intercultural communication process occurred through adjusting to other culture and trying to understand the other's culture. The role of Buru language in intercultural communication are; a) social identity; b) social integration; c) cognitive, and d) escape function. Thus, the local language played an important role as a unifier of a multicultural society.
\end{abstract}

\section{Introduction}

Different cultures have different value systems, therefore, to determine life goals and determine how to communicate effectively are strongly influenced by language, rules, and norms that exist in every culture [1], [2], [3]. Thus, in every communication activity with others, it will be related to the potential for cross-cultural communication, because the owner of a culture will be in a different 'culture' from the others and blend in with a diverse culture, no matter how minimal the difference is [4], [5].

Indonesia is a country that has a diversity of languages and cultures. Indonesian is a national language that unites the variety of languages. Indonesia has many regions with regional languages such as Javanese, Sundanese, Buginese, Butonese, Burunese. Buru Language is one of the local languages of culture in Maluku, Eastern Indonesia. Even though in the Maluku region there are various languages and indeed not all residents in Maluku use the same language and dialect. However, they use Ambon-Malay language as a unifying language, as well as in Buru Island.

Buru Island is one of the districts in Maluku province which is known as an area that has ethnic, cultural and religious diversity. Among the residents living on Buru Island can be distinguished between indigenous people (Geba Bupolo) who live in mountainous areas and migrant residents (Geba Misnit) who live in coastal areas. At present, the population of Geba Misnit is relatively more 
significant compared to Geba Bupolo. Immigrants and natives always claim they are native Buru residents. Geba Bupolo Fuka inhabits a mountainous region. Geba Fuka Unen societies are those who live on the central island, where there is Lake Rana and Mount. Those people who live on the mountain slopes who call themselves Geba Fuka Fafan. Besides, Geba Masin is those who live in coastal areas that interact socially with immigrant communities. Currently, the number of Geba Misnit is relatively larger than Geba Bupolo because of mixed marriages with tribes outside, such as Buton, Bugis, Javanese, Sundanese, Sula, who came to Buru district to work or because of transmigration. However, they always claimed to be residents of Buru [6].

Differences in cultural expectations can cause communication is not smooth, raised an uncomfortable feeling or misunderstanding as a result of a misunderstanding that many of us encounter in various events containing ethnocentrism present in the form of conflicts that led to riots and ethnic opposition. Some of the conflicts in Maluku and Buru are also caused by miscommunication across cultures and regions. As a result, the presence of gold mine in Buru Island since 2012 was often causing conflicts between local citizen and the migrants. The conflicts triggered by the seizure of landmines and also disharmony between cultures and religions [7].

One of the solutions to minimize the miscommunication due to cultural differences is to be aware of diversity or at least to know the language and culture of other people's behavior, knowing the principles of cross-cultural communication and practice in communication with others. The need of cross-cultural study communication is increasingly be felt due to the increasing the openness of the association with people of different cultures, in addition to the condition of the nation, religion, background areas (urban/rural), educational background, and so on.

Based on the background above, the researchers are interested in the study "the role of local language in intercultural communication among societies in Buru Island." In this research, the researchers tried to explore the role and function of Buru language among societies from a different culture. The results hopefully contribute to the theory and model of minimizing the cultural conflict.

\section{Methods}

\subsection{Research Design}

This research aims to analyze the process and the role of intercultural communication that occurs in the multi-cultural family. In revealing a variety of issues and objectives to be achieved, this research employs a descriptive qualitative design. [8] gave his definition of qualitative research focusing on the methodological nature, the complexity of the end product and its nature of the naturalistic inquiry.

\subsection{Informant of the Research}

The researchers gained the data by collecting any literature which has related to the research and then translated the Buru language by the translator which was initially from Buru. Researchers have interviewed and also observed in the field that Buru community between the other cultures is Javanese who lives in BassalaleVillage. The subject of the research is Mr. Belen (come from Burunesse), Mrs. Agustina (come from Ambonese), Mr. Dedy (come from Javanese), Mr. Semion Dawan (chief of the village) and Mr. Malik (translator).

\subsection{The instrument of the Research}

The researcher is directly applicable as a principal investigator (key instrument) which conducted the research process directly and actively interviewing, gathering various materials relating to role Buru language in intercultural communication among societies in Buru island.

\subsection{The technique of Data Collection}

In qualitative research, data collection techniques are needed to get the data in research. Without knowing the techniques of data collection, the researcher will not get the data following what expected. Then, techniques of data collection that use in this researcher are observation, interview, fields note, and documentation. 
ICSCCD 2018

Volume 1, January 2020
p-ISSN 2716-1919 e-ISSN 2716-2907 doi: 10.31327/icusn-adri.v1i0.1055

2.4.1. Observation. Observation is an essential element in qualitative research, observation in a simple concept is the beginning of the process or activity conducted by the researcher to be able to know conditions and realities. Related to intercultural communication research in the role of Buru language then observation conducted by the researcher is the observation within the family and community environment.

In a family environment, the researchers observed how the role of Buru language in intercultural communication among societies, by observing the process of communication that occurs between a husband (Burunesse) and wife (Javanese), husband and children, husband and brother, husband and societies.

The observation in a community environment was performed to determine the communication process conducted by members of the family with the surrounding community. The researchers observed the communication process of family members with neighbors, the communication process when the family members are on societies, communication process dealing with the old friend, and communication process of the family's children.

2.4.2. Interview. The qualitative research interview seeks to describe and the meanings of central themes in the life world of the subjects. The main task in interviewing is to understand the meaning of what the interviewees say [9]. In this research, the interview is essential to obtain data on the role of Buru language in intercultural communication among societies in Buru island. The interview process is useful for strengthening the observation data. The interview was conducted in the form of a discussion to find out the process of intercultural communication that occurs in the family.

2.4.3. Field Note. In this research, field notes are handy for the researchers as an intermediary tool that can see, hear, and feel in data collection. Field note compiled after observation and after conduct interview with the informant. It is to facilitate progress report because the researchers easily forget the data obtained. Therefore, field note can be used as the heart of qualitative research because the data and materials must support a theory in the memory. Similarly, in a research report, everything has to be supported by data that is in the filed in this case is a field record.

2.4.4. Documentation. To support the maximum observation, the researchers used the supporting document. The documentation in this research is something that fundamental as a complement of observation and interview methods such as field notes. The required documentation in this study is various references such as book, writing, and pictures on various matters related to the role of Buru language in intercultural communication among societies in Buru island.

2.4.5. Recording. A common understanding of the recording is a process of recopying an object, whether the object is an image, or any sound, using specific recording media or means that can result files are located on a storage media or not. The concepts of the recording of human outline described that process involves inserting a sound recording sound through a media input and store it in a storage medium.

\subsection{The Technique of Data Analysis}

The researchers used a model analysis by Miles and Huberman [10] who stated that activity in the analysis in the analysis of data on qualitative research conducted interactively and continued through to the end, in which the data are already saturated. The activity of data analysis as disclosed includes three elements; they are data reduction, data display, and conclusion drawing.

2.5.1. Data Reduction. Reduction of data is derived empirically or experimentally into corrected, ordered, and simplified forms. The basic concept is to reduce the amount of diverse data to the meaningful part of the data. 
ICSCCD 2018

Volume 1, January 2020
p-ISSN 2716-1919 e-ISSN 2716-2907 doi: 10.31327/icusn-adri.v1i0.1055

2.5.2. Display Data. In the process of presentation of data, the present researcher data clearly and concisely for ease in understanding the issues examined, in whole or part by part. Miles and Huberman [11] stated that the most frequent from the display of the data for qualitative research data is in the form of narrative text.

2.5.3. Conclusion Drawing. As an interactive model that proposed by Miles and Huberman [10]. From the data collection process, the beginning to record all communication activities that occur in the role in intercultural communication, searching for an explanation to the communication process, see the cause and effect that occurs according to the research problem from the various activities meant, then the research makes conclusions based on initial data found, the data is still provisional. This conclusion can be transformed into the conclusion which is accurate and credible.

\section{Results and Discussions}

\subsection{The Intercultural Communication at Bassalale Village Societies}

Cultural differences and ethnic population of these villages have led to intercultural communication in their daily communications, both in markets, schools, mosques, village meetings, and others. Although different cultures within communities, there never been conflicts among residents caused by the ability of society to communicate and interact very well, it can be described in table 1 below.

Table 1. Intercultural Communication at Bassalale

\begin{tabular}{|c|c|c|c|c|}
\hline \multirow[b]{2}{*}{ Intercultural Communication Process } & \multicolumn{4}{|c|}{ Apprisal } \\
\hline & 1 & 2 & 3 & 4 \\
\hline Social skills & - & - & - & $\sqrt{ }$ \\
\hline Openness & - & $\sqrt{ }$ & - & - \\
\hline Commotion among tribes & - & - & $\sqrt{ }$ & - \\
\hline Conflict resolution & - & - & - & $\sqrt{ }$ \\
\hline Mastering another culture & - & $\sqrt{ }$ & - & - \\
\hline The use of local languages & - & - & - & $\sqrt{ }$ \\
\hline Learn other cultures & - & $\sqrt{ }$ & - & - \\
\hline Adapting to another culture & - & - & - & $\sqrt{ }$ \\
\hline Harmony & - & - & $\sqrt{ }$ & - \\
\hline
\end{tabular}

Note. $1=$ Never $; 2=$ Seldom $; 3=$ Sometimes $;$ and $4=$ Always .

Table 1 shows the observation made got the result that the social capabilities of high society were influenced by openness and respect for differences among cultures. Intercultural communication occurred in the village due to the high society's ability to socialize and communicate with other people, even though they are not very open to other people, but they can understand the differences between cultures.

From the many tribes in Bassalale village, making the village the village Bassalale social rank high among the people. Kinship system refers to the family ties that exist within a society. Kinship systems within communities Bassalale are getting better when there is always a negotiation, no participation, no cooperation, cooperation, harmony and not look at the status.

\subsection{The Role of Buru Language in Intercultural Communication at Bassalale Village}

Several factors undoubtedly influence the existence of intercultural communication in the village, but the most crucial factor that researchers have found is the roles of language hunt itself as the unifying language and familiarity among residents to avoid conflicts between cultures or ethnicity, the role of language hurry it can be seen in table 2 below. 
Table 2. The Role of Intercultural Communication

\begin{tabular}{lllll}
\hline \multirow{2}{*}{ The Role of Intercultural Communication } & \multicolumn{3}{c}{ Scoring } & \\
\cline { 2 - 5 } & 1 & 2 & 3 & 4 \\
\hline Social Identity Function & - & - & - & $\sqrt{ }$ \\
Social Integration Function & - & - & - & $\sqrt{ }$ \\
Increase Knowledge (Cognitive) & - & - & - & $\sqrt{ }$ \\
Escape or as a way out & - & - & $\sqrt{ }$ & - \\
Monitoring & - & $\sqrt{ }$ & - & - \\
Connecting & - & $\sqrt{ }$ & - & - \\
Socializaation & - & $\sqrt{ }$ & - & - \\
Entertaining & - & $\sqrt{ }$ & - & - \\
\hline
\end{tabular}

Note. $1=$ Never $; 2=$ Seldom $; 3=$ Sometimes; and $4=$ Always.

The table 2 shows that the dominant role of intercultural communication in among societies in Buru Island is residence in Bassalale village were social identity, social integration, increase knowledge, and escape. The social factor is a dominant factor in the role of language hurry because the state of the high community social skills and become a unifying function in communication. The local language is also a means of knowledge to society, and capable of supporting vocabulary in different cultures.

3.2.1. Social Identity Function. Based on the observation, the researcher found social identity function in this communication. It can be seen when Mr. Belen buy in Mr. Dedy bookstore.

Mr. Belen : Pak Dedy ada jual buku tulis?

(Mr. Dedy, are there notebooks sold?)

Mr. Dedy : Iya ada pak, mau beli berapa? (yes sir, how many books do you want to buy?)

Mr. Belen : save sian ba (just one) (rising up his index finger)

Mr. Dedy : Pak Belen asli orang Buru ka? (is Mr. Belen is a native people of Buru?)

Mr. Belen : iya pak, barang kenapa? (yes I am, why?)

Mr. Dedy :Gak, Cuma tanya saja. Soalnya pak punya logat menunjukkan bahwa pak Belen itu orang Buru.

(No, Just asking. Because your accent indicates that you are Burunesse).

3.2.2. Make Relationship function. The researcher found that the communication in Buru community when Mr. Belen accosts Mrs. Rose.

Mr. Belen : Selamat pagi ibu Rose? ada mau pi kamana? (good morning Mrs. Rose, where are you going?)

Mrs. Rose : Pagi juga pak Belen. Mau pi ambil rapot di sekolah. (Morning Mr. Belen. I Want to take raport in the school)

Mr. Belen : Do bagi rapot hai?

(Is it already gave?)

Mrs. Rose : Heeta, hangina na. (already sir, today)

Mr. Belen : dangkua pa ya nganat dabina yakomo. Ya tewa be hangina na bagi raport mo. (wow, why my child does not say. Well I do not know if there was a division rapport) 
3.2.3. Delivering Secrets. By using the local language, it is generally easier to tell a secret. Researchers discovered this case in a conversation between the family and the Mrs. Agustina and Mr. Belen. The conversation below is between the family and the Mrs. Agustina and Mr. Belen.
Mr. Belen
: Leni.. dari tadi bapa liat ose ni jajan tarus
(Leni .. I saw you from moments always buy the snack)
Ms. Leni
: Seng bapa, cuma sadiki sa
(No sir, only a little)
Mr. Belen
: Panggel ose punk mama kamari.
(Call your mother to come here)
Mrs. Agustina : come in Mr. Belen when they are sit in the family room.
Mr. Belen : eta huke kepeng jajan lai gebaranan, bara warot.
(you know, do not give much money for the child to buy the meal)
Mrs. Agustina : heeta yu huke warot moo.
(yes, I will reduce their allowances)

3.2.4. Social Integration Function. The researcher found that this case can accept the difference between culture, for example, there is a different type of food between the two cultures, but they are still able to accept it.
Pak Dedy : Pak singgah dulu, jangan buru-buru pulang masih panas (first stop sir, do not rush home still hot)
Pak Belen : iyo ni paleng panas (yes this so hot)
Pak Dedy : mari minum cendol dulu (Let's drink first Cendol)
Pak Belen : apa itu cendol? (what is Cendol?)
Pak Dedy : minuman khas orang jawa. (typical drink Javanese people)
Pak Belen : bawa kamari sudah, mumpung haus lai ni. (brought here already, there is thirst)

3.2.5. Social Function. One function is the local language as a social function that is unifying role in the lives of people, especially the dominant Bassalale by using Buru language in communication as a tool of daily communication.

3.2.6. Escape of as a Way Out. The function of intercultural communication in the role of Buru language is if there's a problem in the family or with neighbors, Mr. Belen always discuss it uses Buru language and Ambon language. The data discoveries indicate the presence of intercultural communication in the Bassalale Village, intercultural communication in the Bassalale village hamlet Waesgoret common in many places such as in roads, markets or when gathering at home.

In the Bassalale village have many parts between primitive society, ethnic Javanese, Buginese, Sundanese, and Ambonese. Although there are many tribes in the village of Basalale, the intercultural conflicts can be resolved with both communication and discussion. Even the language was wanted in the village Basalale made as a unifying language in order to avoid conflict. It is in line with the how intercultural communication proposed by [12] "This model aims to improve interaction in understanding, respecting, tolerating, and integrating cultural differences".

The intercultural communication occurs in Bassalale village could be seen from the data taken by the researcher through observation and interview. The observation data and interview explain the informants can understand each other, understand the feelings, and act together. It is seen from the way they communicate with each other, although the societies with the other culture and different 
ICSCCD 2018

Volume 1, January 2020
p-ISSN 2716-1919 e-ISSN 2716-2907 doi: 10.31327/icusn-adri.v1i0.1055

cultures and do not know the local language each other, the communication occurs societies can continue run smoothly, and they communicate using the Indonesian language. As for the little barriers that caused by cultural differences and differences in perception, but it does not become a problem for them.

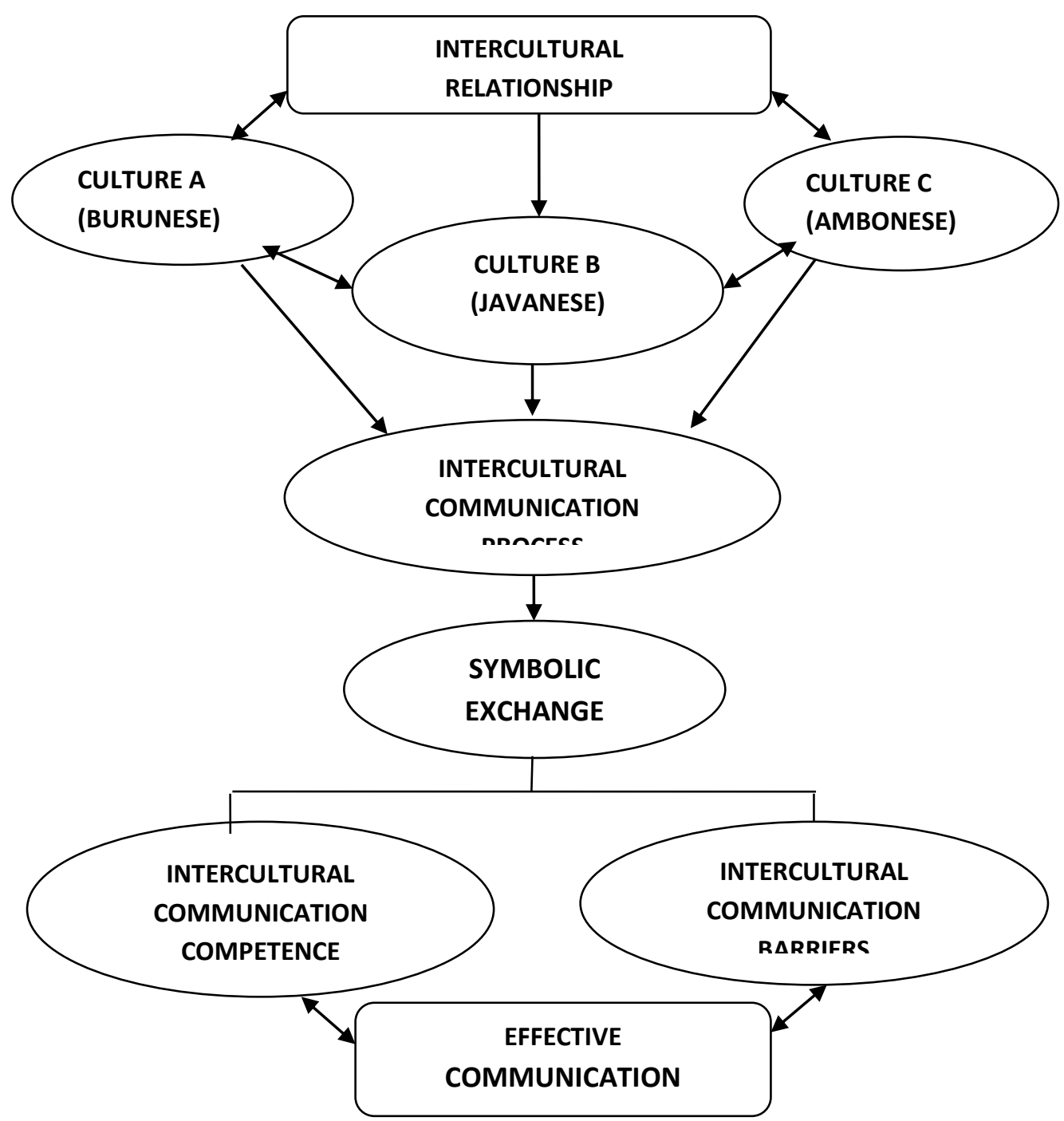

Figure 1. Intercultural Communication Model (source: Data Analysis, 2016)

Based on the chart above can be seen that the process of intercultural communication occurs societies by way of exchange of symbols verbal and nonverbal, and if the exchange process that is barriers, communicators, and communicant can handle with the competence of intercultural communication and cultural awareness that they have to form effective communication.

\section{Conclusion}

By the findings and discussion, the researchers concluded that: (1) The intercultural communication in the Bassalale village was unique because there are many cultures, including the primitive society of Burunese, Javanese, Sundanese, Buginese, and Ambonese. From the five tribes were highly influential in the process of intercultural communication is a Buru. The openness and the ability of civil society, ability to create a harmonious intimacy between tribes. Commotion or conflict can be 
adequately resolved. Intercultural adaptation becomes very dominant in the Bassalale village. Intercultural communication that often occurs in the Bassalale village usually found in Waesgoret where the village has dominated the population of different tribes living side by side; (2) The role and functions of intercultural communication in Buru language among societies in Buru island are: a) social identity function to inform each other about their social identity to family, friends, and society through action, verbal and non verbal language; b) social integration function to accept the cultural differences ; c) cognitive function to reveal that the cultural differences between them to make them acquire knowledge about the culture of their mate; and d) escape function to explain if there is a problem they usually find a way out by discussing the problem.

\section{Reference}

[1] Kroeber, Kluckhohn and A.L,C. (1952). Culture: A critical review of concepts and definitions. Harvard University peabody Museum of American Archeology and Ethnology papers 47.

[2] Byram, M., Nichols, A., \& Stevens, D. (Eds.). (2001). Developing intercultural competence in practice (Vol. 1). Multilingual Matters.

[3] Fantini, A. E. (2000). A central concern: Developing intercultural competence. SIT Occasional Paper Series, 1, 25-42.

[4] Bin-Tahir, S. Z., \& Rinantanti, Y. (2016). Multilingual Lecturers' Competence in English Teaching at the University of Iqra Buru, Indonesia. Asian EFL Journal, 5, 79-92.

[5] Bin-Tahir, S. Z., Bugis, R., \& Tasiana, R. (2017). Intercultural Communication of a Multicultural Family in Buru Regency. Lingual: Journal of Language and Culture, 9(2), 8-17.

[6] Taher. (2013). Mengenal Pulau Buru. Online. Accessed From. http://dityataher.blogspot.co.id/2013/10/mengenal-pulau-buru_9.html.

[7] Tempo. (2012). Kronologi Konflik di Maluku, Online. Accessed From http://tempo.co.id/hg/timeline/2012/04/29/tml,20040429-01,id.html.

[8] Creswell, J. W. (1998). Qualitative inquiry and research design: Choosing among five tradition.

[9] Haraldsen, G., Kvale, D., Lien, B., Farstad, I. N., \& Brandtzaeg, P. (1996). Cytokine-regulated expression of E-selectin, intercellular adhesion molecule-1 (ICAM-1), and vascular cell adhesion molecule-1 (VCAM-1) in human microvascular endothelial cells. The Journal of Immunology, 156(7), 2558-2565.

[10] Bungin, B. (2007). Analisis data penelitian kualitatif. Jakarta; PT Raja Grafindo Persada.

[11] Sugiyono. (2007). Metode Penelitian Pendidikan Pendekatan Kuantitatif, Kualitatif dan R\&D. Bandung: Alfabeta.

[12] Chen \& Starosta. (1996). Intercultural Communication Competence: A Synthesis. Communication Year book. 